\section{Effect of Dry Storage on Bacterial Counts in Stems of Cut Rose Flowers}

\author{
Wouter G. van Doorn and Yke de Witte \\ Agrotechnological Research Institute, P. 0. Box 17, 6700 AA \\ Wageningen, Holland
}

Additional index words. Rosa hybrida, aluminum sulfate, cooling, xylem occlusion

\begin{abstract}
The number of bacteria in the basal $5 \mathrm{~cm}$ of the stems of cut rose flowers (Rosa hybrida L. cv. Sonia) stored in water for 1 to 4 days was positively correlated with the number of bacteria in the water. Subsequent dry storage of the flowering rose stems resulted in an increase in the number of bacteria in the stems, similar to that occurring in stems that were held in water. Low temperatures during dry storage (SC) reduced the reproduction rate of bacteria in the stems. Use of aluminum sulfate $(0.8$ g-liter-') during the rehydration period before dry storage limited the number of bacteria in the stems and prevented their subsequent increase during dry storage.
\end{abstract}

Addition of antimicrobial compounds to the vase water has been found to increase longevity of many cut flowers (Aarts, 1957), whereas the inclusion of a high number of bacteria in the vase water has been found to reduce longevity (Van Doorn et al., 1986; Zagory and Reid, 1986).

After placing the stems in water for 2 to 3 days, a high bacterial count was found at the cut surface and inside the xylem vessels of rose stems, which was correlated with a decrease in hydraulic conductance of the stems and which may explain why rose flowers often wilt within 2 to 3 days (Van Doom et al., 1989; 1991a).

Harvesting the stems and placing them in water shortly after harvest may introduce bacteria at the cut surface and in the xylem interior. At the growers' premises, the cut rose flowers are often stored for rehydration in water generally held at low temperature (1 to 4C). The water used for rehydration of the flowers may be up to several weeks old and contain a high number of bacteria, especially when no antimicrobial compounds are included. Some time after rehydration the flowering stems will be stored dry (or transported dry) at temperatures ranging from 1 to more than $20 \mathrm{C}$.

We hypothesized that the growth rate of the bacterial population associated with rose stems would be higher when stems were held in water than during dry storage. This hypothesis was tested by holding stems in solutions and then keeping stems dry or in sterile water. The effect of temperature during dry storage was compared at 20 and 5C. The effect of aluminum sulfate, a common antibacterial compound that is included in the water used by growers for rehydration, was also investigated, as it is claimed that this substance would prevent the further development of the bacterial population in the rose stems.

Received for publication 30 Nov. 1990. The cost of publishing this paper was defrayed in part by the payment of page charges. Under postal regulations, this paper therefore must be hereby marked advertisement solely to indicate this fact.
Methods. 'Sonia' rose flowers were obtained from a commercial grower, held dry after cutting, and brought to the laboratory within 3 to $4 \mathrm{~h}$. In the laboratory, the leaves were removed until the uppermost five leaves with five or more leaflets remained, and 40 stems were placed in tap water in a IO-liter plastic container at $4 \mathrm{C}$ in darkness and left in the water for 1 to 4 days. Twenty roses were taken out of the solution, wrapped in paper, placed in a flower box, and held dry for $15 \mathrm{~h}$ at 20 or $5 \mathrm{C}$. In controls that were not held dry, the stems were placed in sterile water in a sterile glass container.

The number of bacteria in the water was determined when the flowers were taken out of the solution. The water was stirred before sampling. A decimal dilution series was placed on Plate Count Agar (Oxoid, Basingstoke, Hants., U.K.) using the spiral plate method (model C, Spiral Plate Systems, Cincinnati). Petri dishes were kept at 30C for $48 \mathrm{~h}$ before enumeration.

The number of bacteria in the lowermost $5 \mathrm{~cm}$ of stems was determined after storage in water and after simulation of dry storage using the method of Van Doorn et al. (1989).

The growth rate of the bacterial population

Table 1. Number of bacteria in the basal $5 \mathrm{~cm}$ of 'Sonia' rose stems stored dry or in sterile water at 20C.

\begin{tabular}{|c|c|c|c|c|}
\hline \multicolumn{3}{|c|}{ Bacterial count $\left(\mathrm{cfu} / \mathrm{g} \text { fresh wt } \times 10^{4}\right)^{x}$} & \multirow{2}{*}{\multicolumn{2}{|c|}{$\begin{array}{l}\text { Rate of population growth } \\
\text { during storage (increase } / \mathrm{h} \text { ) }\end{array}$}} \\
\hline \multirow{2}{*}{$\begin{array}{l}\text { Before } \\
\text { storage }\end{array}$} & \multicolumn{2}{|c|}{ After storage } & & \\
\hline & Dry & In water & Dry & In water \\
\hline $\begin{array}{r}2 \mathrm{a} \\
420 \mathrm{c} \\
\end{array}$ & $\begin{array}{r}40 \mathrm{~b} \\
3800 \mathrm{~d} \\
\end{array}$ & $\begin{array}{r}30 \mathrm{~b} \\
2400 \mathrm{~d}\end{array}$ & $\begin{array}{l}0.19 \\
0.15\end{array}$ & $\begin{array}{l}0.17 \\
0.12\end{array}$ \\
\hline
\end{tabular}

${ }^{z}$ Values are means of three replications. Mean separation at $P<0.05$.

Table 2. Effect of temperature (5 and 20C) during dry storage on the development of a bacterial population in the basal $5 \mathrm{~cm}$ of 'Sonia' rose stems.

Bacterial count $\left(\mathrm{cfu} / \mathrm{g} \text { fresh wt } \times 10^{4}\right)^{2}$

\begin{tabular}{|c|c|c|c|c|}
\hline \multicolumn{3}{|c|}{ Bacterial count $\left(\mathrm{cfu} / \mathrm{g} \text { fresh wt } \times 10^{4}\right)^{2}$} & \multirow{2}{*}{\multicolumn{2}{|c|}{$\begin{array}{l}\text { Rate of population growth } \\
\text { during storage (increase } / \mathrm{h} \text { ) }\end{array}$}} \\
\hline \multirow{2}{*}{$\begin{array}{c}\text { Before } \\
\text { dry storage }\end{array}$} & \multicolumn{2}{|c|}{ After dry storage } & & \\
\hline & $5 \mathrm{C}$ & $20 \mathrm{C}$ & $5 \mathrm{C}$ & $20 \mathrm{C}$ \\
\hline $\begin{array}{r}1 \mathrm{a} \\
460 \mathrm{c}\end{array}$ & $\begin{array}{r}3 \mathrm{a} \\
2200 \mathrm{c}\end{array}$ & $\begin{array}{r}48 \mathrm{~b} \\
7100 \mathrm{~d}\end{array}$ & $\begin{array}{l}0.05 \\
0.10\end{array}$ & $\begin{array}{l}0.24 \\
0.18\end{array}$ \\
\hline
\end{tabular}

${ }^{2}$ Values are means of three replications. Mean separation at $P<0.05$. lated $\left(r^{2}=0.94\right)$ with the number of bacteria in the solution, measured when the stems were taken out of the solution (Fig. 1). This correlation was found at all investigated numbers of bacteria in the water and was the period of storage (1 to 4 days). The correlation may be practically useful as it allows an estimate of stem contamination simply by measuring the wer of bacteria in the water.

Wacrs were held in water containnumber of bacteria in the basal $5 \mathrm{~cm}$ of the stems increased during dry storage (Fig. 1). When the initial number of bacteria in the basal $5 \mathrm{~cm}$ did not exceed $10^{7} \mathrm{cfu} / \mathrm{g}$ fresh weight, the rate of population increase durunits/h and was independent of the size of the initial population (results not shown).

Flowers held dry for $15 \mathrm{~h}$ at $20 \mathrm{C}$ showed an increase in bacterial count in the lowermost 5-cm segment of the stem. This increase was the same as in flowers held in sterile water (Table 1). The high growth rate of the bacterial population during dry storage was unexpected, as it was presumed that the (v, increase/hour) in stems was calculated according to Schlegel (1985): $\mathrm{v}=(\ln \mathrm{b}$ a), in which a is the number of bacteria ore $c$ hours of storage, and $b$ is the num-

of bacteria after storage.

flowers were placed in a solution of $0.8 \mathrm{~g}$ $\mathrm{Al}_{2}\left(\mathrm{SO}_{4}\right)_{3} \cdot 18 \mathrm{H}_{2} \mathrm{O} /$ liter $(\mathrm{pH} 4.1)$ for $24 \mathrm{~h}$ at $20 \mathrm{C}$ before the onset of dry storage. Results were compared by analysis of variance and F tests, using the GENSTAT V Statistical Package (Rothamsted, U.K.).

Bacteria in water and stems. The number of bacteria in the water in which cut roses (Fig 1). The same exponential increase was found in the number of bacteria associated with the basal $5 \mathrm{~cm}$ of the stems. When the flowers had been held in the solution for 1 to 4 days, the number of bacteria in the basal $5 \mathrm{~cm}$ of the stems (in colony-forming units

HortSCience, Vol. 26(12), December 1991 
Table 3. Effect of including aluminum sulfate $\left(0.8 \mathrm{~g} \cdot \mathrm{liter}^{-1}\right)$ in the water on the number of bacteria in the basal $5-\mathrm{cm}$ stem segment of cut 'Sonia' rose flowers during dry storage at 20C. Flowering shoots were held in water for $24 \mathrm{~h}$ before dry storage.

\begin{tabular}{|c|c|c|c|}
\hline \multirow{2}{*}{$\begin{array}{l}\text { Aluminum } \\
\text { sulfate }\end{array}$} & \multicolumn{2}{|c|}{ Bacterial count $\left(\mathrm{cfu} / \mathrm{g} \text { fresh wt } \times 10^{4}\right)^{2}$} & \multirow{2}{*}{$\begin{array}{c}\text { Rate of population } \\
\text { growth during storage } \\
\text { (increase } / \mathrm{h} \text { ) }\end{array}$} \\
\hline & Before dry storage & After dry storage & \\
\hline+ & $\begin{array}{l}0.9 \mathrm{a} \\
0.2 \mathrm{a}\end{array}$ & $\begin{array}{r}70.3 \mathrm{~b} \\
0.2 \mathrm{a}\end{array}$ & $\begin{array}{l}0.29 \\
0.00\end{array}$ \\
\hline
\end{tabular}

${ }^{\mathrm{z}}$ Values are means of three replications. Mean separation at $P<0.05$.

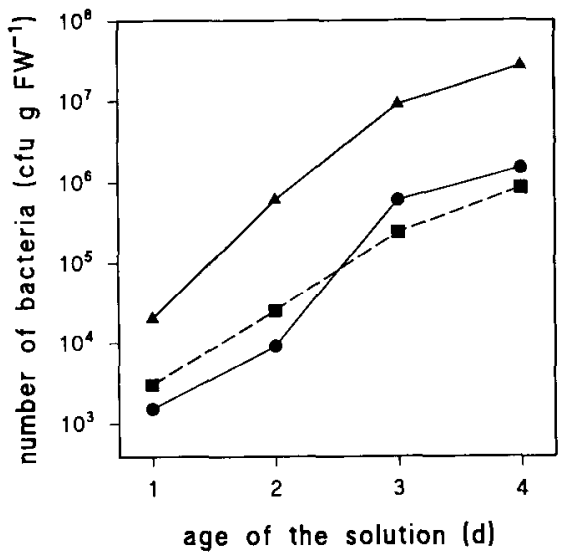

Fig. 1. Effect of storing cut flowering 'Sonia' rose stems in water or in air on the bacterial count in the water and in the basal $5 \mathrm{~cm}$ of the stems. Stems were held in an aqueous solution (at 4C) for 1 to 4 days, and the number of bacteria (cfu per milliliter) in the solution ( $)$ was counted when the stems were taken out. The number of bacteria in stems (cfu per gram fresh weight) were measured when the stems were removed from the solution ( $\square$ ) and after $15 \mathrm{~h}$ of dry storage at $20 \mathrm{C}(\boldsymbol{\Delta})$.

cut surface of the stem and the xylem vessels in which the bacteria were present (Van Doom et al., 1990b, 1991a, 1991b) would contain little water.

During dry storage at $5 \mathrm{C}$, the increase in bacterial count was smaller than during dry storage at 20C (Table 2), but the bacterial count in the lowermost $5 \mathrm{~cm}$ of the stem increased, as in flowers held in sterile water at $5 \mathrm{C}\left(3.1 \times 10^{4}\right.$ and $14.1 \times 10^{6} \mathrm{cfu} / \mathrm{g}$ fresh weight were found after initial bacterial counts of $1.3 \times 10^{4}$ and $4.6 \times 10^{6} \mathrm{cfu} / \mathrm{g}$ fresh weight, respectively). The results indicate that the temperature during storage should be kept low not only to reduce the rate of metabolism in the flowering stems, but also to reduce the growth rate of the bacterial population associated with the cut surface and the xylem interior.

Stems placed in a freshly made solution of $0.8 \mathrm{~g}$ aluminum sulfate/liter for $24 \mathrm{~h}$ before dry storage had a low bacterial count in the water (not shown) and in the stems (Ta- the bacterial population in rose stems during dry storage.

\section{Literature Cited}

Aarts, J.F.T. 1957. Over de houdbaarheid van snijbloemen. Mededelingen Landbouwhoge School Wageningen 57(9):1-62.

De Stigter, H.C.M. 1981. Effects of glucose with 8-hydroxyquinoline sulfate or aluminum sulfate on the water balance of cut 'Sonia' roses. Z Pflanzenphysiol. 101:95-105.

ble 3). This treatment prevented the increase in the number of bacteria in the stems during subsequent dry storage (Table 3 ).

Aluminum sulfate included in the vase water of cut rose flowers has been found to prevent premature wilting (De Stigter, 1981; Halevy et al., 1978; Schnabl, 1976; Schnabl and Ziegler, 1974; Weinstein and Laurencot, 1963). The effect on longevity was correlated with a decrease in the number of bacteria associated with the stems, measured 7 days after placing the stems in water (Van Doorn et al., 1990a). In rose stems placed in a freshly made solution of aluminum sulfate at $0.8 \mathrm{~g} \cdot \mathrm{liter}^{-1}$, bacterial counts in the water and in stems remained low, while counts did not increase during subsequent dry storage.

Schnabl and Ziegler (1975) found stomatal closure in epidermal strips of Vicia faba by aluminum ions and suggested that this might also be one reason why aluminum sulfate prolongs longevity of cut rose flowers. Whether $\mathrm{Al}^{+3}$ may reach the epidermis in cut flowering roses placed in a solution containing the aluminum ions is not clear. Veen and Van de Geijn (1978) showed low mobility of $\mathrm{Ag}^{+}$in stems, as it was bound by the negative charges on the xylem walls. The mobility of $\mathrm{Al}^{+3}$ may be even lower.

The use of aluminum sulfate may, however, also result in damage when the stems are placed in the solutions for an extended period or when the concentrations are high. In a continuous treatment at $0.8 \mathrm{~g}$ aluminum sulfate/liter at 20C, 'Sonia' roses showed leaf abscission after $\approx 5$ days (Van Doom et al., 1990a). It is a standard practice in the Netherlands to place the stems overnight, or at most for 2 to 3 days, in such solution held at 1 to $4 \mathrm{C}$. After these treatments, the leaves do not show premature abscission. In the present experiments (treatment for $24 \mathrm{~h}$ at 20C) no damage was observed either.

Some aluminum compounds apparently adhere to the cut surface and to the walls of the xylem vessels, as a white deposit was noted at the cut surface of stems held in the aluminum sulfate solution. The continuous presence of the aluminum compounds may be the cause of the inhibition of growth of
Halevy, A.H., T. G. Byrne, A.M. Kofranek, D.S. Farnham, J.F. Thompson, and R.E. Hardenburg. 1978. Evaluation of postharvest handling methods for transcontinental truck shipments of cut carnations, chrysanthemums, and roses. J. Amer. Soc. Hort. Sci. 103:151-155.

Schlegel, H.G. 1985. Allgemeine Mikrobiologie. Georg Thieme, Stuttgart.

Schnabl, H. 1976. Aluminiumionen als Frischhaltemittel für Schnittblumen. Deutsch. Gartenbau 30:859-860.

Schnabl, H. and H. Ziegler. 1974. Der Einfluss des Aluminiums auf den Gasaustausch und das Welken von Schnittpflanzen. Ber. Deutsch Bot. Ges. 87:13-20.

Schnabl, H. and H. Ziegler. 1975. Über die Wirkung von Aluminium auf die Stomatabewegung von Vicia faba- Epidermen. Z. Pflanzenphysiol. 74:394-403.

Van Doom, W.G., H.C.E.M. Buis, and Y. de Witte. 1986. Effect of exogenous bacterial concentrations on water relations of cut rose flowers. II. Bacteria in the vase solution. Acta Hort. 181:463-465.

Van Doorn, W.G., R.R.J. Perik, and Y. de Witte 1990a. Effect of antimicrobial compounds on the number of bacteria in stems of cut rose flowers. J. Appl. Bacteriol. 68:117-122.

Van Doorn, W.G., K. Schurer, and Y. de Witte. 1989. Role of endogenous bacteria in vascula blockage of cut rose flowers. J. Plant Physiol. 134:375-381.

Van Doom, W.G., H.C.M. de Stigter, Y. de Witte, and A. Boekestein. 1991a. Micro-organisms at the cut surface and in xylem vessels of rose stems: A scanning electron microscope study. J. Appl. Bacterial. 68.

Van Doorn, W.G., F. Thiel, and A. Boekestein. 1990b. Cryo-scanning electron microscopy of extracellular polysaccharide produced by bacterial colonies. Scanning 12:297-299.

Van Doorn, W.G., F. Thiel, and A. Boekestein. 1991b. Examination of occlusions in xylem vessels of cut rose flowers, using cryoscanning electron microscopy and cryoultramilling crosssectioning. Scanning 13:37-40.

Veen, H. and S.C. van de Geijn. 1978. Mobility and ionic form of silver as related to longevity of cut carnations. Planta 140:93-96.

Weinstein, L.H. and H.J. Laurencot. 1963. StudBoyce Thompson Inst. 22:81-90.

Zagory, D. and M.S. Reid 1986. Role of vase solution micro-organisms in the life of cut flowers. J. Amer. Soc. Hort. Sci. 111:154-158. ies on the preservation of cut flowers. Contrib. 